\title{
Aproximações poéticas entre produção cultural indígena e a obra de Celeida Tostes \\ Beatriz Vianna Reis ${ }^{1}$ \\ DOI 10.20396/eha.vi14.3419
}

Não é exagero afirmar que todos os povos, em todos os continentes, em algum momento de sua história descobriram como trabalhar e transformar o barro, dando corpo a sua cultura através da argila. Mil povos habitavam o território onde hoje fica o Brasil e muito de suas tradições pode ser recontada a partir da produção cultural em cerâmica. Urnas funerárias, cumbucas, panelas e outros utilitários, por vezes ricamente ornamentados, sobreviveram ao genocídio que sucedeu o ano da chegada dos Portugueses à costa. Até hoje, diversas etnias produzem peças em cerâmica como forma de preservar um conhecimento ancestral e valorizar a cultura local.

Com os europeus, chegou ao Brasil a tradição da cerâmica asiática, caracterizada pela massa branca e decoração com pigmentos azulados. A prática se espalhou e hoje está presente em todos os estados do país. Por muitos anos, foi considerada "arte menor", não encontrando espaço nas instituições de arte - e a cerâmica ancestral indígena foi relegada aos museus de antropologia e etnologia, onde serviam para ilustrar a história do "outro". ${ }^{2}$ Nas últimas décadas, no entanto, alguns artistas começaram a trabalhar com o barro e ele foi, aos poucos, conquistando espaço em grandes exposições e bienais. Celeida Tostes, artista carioca nascida em 1929 e morta em 1995, foi um dos grandes nomes nacionais a fazer do barro o protagonista em sua obra e a levar a cerâmica para o circuito de arte contemporânea.

Celeida estudou na Escola Nacional de Belas Artes, onde se formou em Gravura. Na época, foi aluna de Oswaldo Coeldi e participou, em 1955, da exposição "Gravuristas Brasileiros", coletiva que viajou por diversos países. Em 1958, foi contemplada com uma bolsa de estudos na Universidade Southern, na Califórnia, e na Universidade New Mexico Highlands, no Novo México. Durante seu período nos Estados Unidos, foi aprendiz da índia Navajo Maria Martinez (1887-1981), conhecida como a Oleira de San Ildefonso. Com ela, aprendeu como trabalhar a terra e "segundo a própria Ce-

1 Doutoranda no Programa de Pós-Craduação em Arte Visuais da UFR], mestra em Artes Visuais pela mesma instituição e bolsista CAPES.

2 Mais sobre a história da cerâmica no Brasil, consultar PRADO, 2016 e SANTOS, 2011. 
leida, a convivência foi decisiva para a escolha do barro como matéria-prima de seu trabalho". ${ }^{3} \mathrm{De}$ volta ao Brasil, a artista participou de diversas exposições e trabalhou como professora da Rede Estadual de Ensino do Rio de Janeiro. Em 1975, inaugurou a Oficina das Artes do Fogo e Transformação de Materiais no Parque Lage, e em 1989, tornou-se professora da Escola de Belas Artes da Universidade Federal do Rio de Janeiro, onde criou a Oficina Integrada de Cerâmica. Desenvolveu com seus alunos um trabalho experimental e sensorial que tinha por base vasta pesquisa e manipulação do universo cerâmico.

Nos cursos oferecidos pela artista eram realizados rituais de sensibilização e criatividade ao ar livre, exploração de relações sensoriais com os quatro elementos: água, fogo, terra e ar. Ensinamentos e experimentos da transformação de materiais sob a ação do fogo. Celeida não ensinava técnicas ou fórmulas pré-estabelecidas para seus alunos; ela pregava a liberdade da descoberta e a criação de linguagens próprias. A oficina era uma espécie de laboratório de alquimia, em que criavam objetos com a ajuda da natureza. ${ }^{4}$

Celeida produzia séries de peças em grandes quantidades. Fendas, vaginas, úteros, seios, bolas, aos milhares. Moldava-as no bojo de suas mãos e em seu próprio corpo. Em 1979, realizou sua obra mais emblemática, a performance "Passagem". Sem espectadores, cobriu-se de barro e encerrou-se em um enorme vaso de argila crua, que foi lacrado por duas assistentes. Depois, rompeu as paredes do pote, como um parto. A relação da artista com o feminino era intensa. ${ }^{5}$ Dizia,

Para mim, no paleolítico superior, o nascimento das "Vênus", ao que se tem confirmação até agora, deu-se no bojo das mãos. Como se a mão fosse o ventre. Assim, o aperto reflexo da mão no material mole, que também é relação de magia, relação com o corpo da mulher, com a agricultura e a fartura, deu origem às Vênus. ${ }^{6}$

Ao contrário das cerâmicas de Celeida, expostas em grandes instituições de arte, a produção cultural indígena em argila dificilmente circula fora dos museus de antropologia. Em 2005, no ano do Brasil na França, o Ministério da Cultura em parceria com o governo francês realizou uma exposição nas Galerias Nacionais do Grand Palais, em Paris, intitulada Brèsil Indien: les arts des Amérindiens du Brèsil (Brasil Indígena: as artes dos ameríndios do Brasil). A exposição reuniu cerca de trezentos e cinquentas objetos - centenas de peças em cerâmica -, vindos de museus brasileiros e europeus, além de registros fotográficos e audiovisuais, divididos em sete eixos temáticos, que contempla-

\footnotetext{
3 COSTA e SILVA, 2014, p. 222

4 COSTA e SILVA, 2014, p. 224

5 Sobre Celeida Tostes e o feminino, consultar HENNIG, 2008.

6 HENNIG, 2008, p. 19
} 
vam milhares de anos de história, do ancestral ao contemporâneo.

Os povos ameríndios originários são faziam uso do conceito de "arte" e nem pensavam em suas produções culturais como obras de arte. ${ }^{7}$ Quando esses objetos ocupam lugar em instituições culturais ocidentais ou quando passam por um processo de artificação, é para que nós, os espectadores, sejamos capazes de nos relacionarmos com as peças de forma mais confortável, através dos conceitos e chaves de leitura que dominamos.

Este artigo pretende abordar a produção cultural indígena em cerâmica presente no catálogo desta exposição, em diálogo com a obra da artista Celeida Tostes, a fim de desenhar aproximações formais e poéticas entre esses objetos. Dessa forma, a pesquisa tenciona evidenciar "afinidades eletivas estruturais"9 entre a cerâmica ancestral indígena e a cerâmica contemporânea inserida em circuitos de arte. O que se propõe aqui - e que segue em desenvolvimento através de tese de doutorado - é uma linguagem própria do barro, que se repete e sobrevive através do tempo. Por meio de um procedimento de montagem, onde as imagens do catálogo da exposição Brèsil Indien e as do catálogo da artista Celeida Tostes são colocadas lado a lado, se pretende apontar para algo que é guiado pela matéria. Um modo de fazer próprio do barro, que escapa à História da Arte ou ao cronológico, e se insere em uma lógica anacrônica. Um repertório de gestos próprios do modelar com as mãos, formas que se pode conseguir através da argila. Um vocabulário telúrico responsável por embaçar as distâncias sociais, culturais e temporais entre os objetos, apontando para um aspecto acrônico da terra.

Entre 1927 e 1929, o historiador alemão Aby Warburg trabalhou em uma série de painéis onde investigava a sobrevivência do Renascimento na Europa. Bilderatlas Mnemosyne não organiza a história da arte de modo cronológico e o modelo historiográfico proposto por Warburg rejeita os pares "vida e morte", "grandeza e decadência" etc. - há muito reivindicados como centrais para a disciplina. Também em 1927, Walter Benjamin - que, diga-se de passagem, não conhecia Warburg - começou a escrever o seu "Passagens" (1927 -1940), uma de suas obras mais complexas, onde escava a Paris da virada do século, que se transformava velozmente pelas reformas propostas por Haussman, através de escritos curtos. Segundo Didi-Huberman, os dois colocavam a imagem no "centro nevrálgico da 'vida histórica', e compreendiam "que esse ponto de vista exigia a elaboração

\footnotetext{
7 Segundo Els Lagrou, os indígenas "não somente não têm palavra ou conceito equivalente aos de arte e estética (...), como parecem representar, no que fazem e valorizam, o polo contrário do fazer e pensar do Ocidente neste campo." (LAGROU, 2009, p. 11)

8 Artificação é um conceito de Roberta Shapiro e Nathalie Heinich que designa um "processo dinâmico de mudança social, através do qual novos objetos e práticas emergem, pelo qual relações e instituições são transformadas". Nesse caso, os artefatos indígenas transformam-se em objetos de arte e são exibidos como tal. (SHAPIRO e HEINICH, 2012)

9 DIDI-HUBERMAN, 2012.
} 
de novos modelos de tempo: a imagem não está na história como um ponto sobre uma linha."10 Cada um a seu modo, Warburg e Benjamin não reduziam a imagem a um documento da história, mas também não a viam apenas como um "puro momento do absoluto" 11.

A imagem, portanto, se encontra em um lugar medianeiro que instaura um modelo de tempo anacrônico e deve ser compreendida de forma sintomal, ou seja, a partir do presente que inaugura e não do passado a que faz referência. Tanto Warburg quanto Benjamin apresentam uma saída à historiografia cronológica. A partir deles, é possível pensar em uma história da arte "a contrapelo"12, que contempla, de forma mais ampla, outras vozes e saberes muitas vezes ignorados na narrativa tradicional. É por isso, aliás, que o artigo se propõe a trabalhar com fotografias de catálogo - selecionadas e editadas -, pois é no âmbito da imagem que se pode pensar, à princípio, uma história da arte anacrônica. E, bem como Warburg, a questão foi abordada a partir da montagem de painéis, a fim de ampliar o "leque antropológico"13 da terra. (Figura 1, Figura 2, Figura 3, Figura 4)

A escolha das imagens e a forma como foram organizadas (colocadas lado a lado, justapostas, contrapostas etc.) se deu de forma subjetiva - mesmo que aspectos formais tais como cores e texturas tenham sido levados em conta. A tarefa, mais do que um exercício conceitual, tratou-se de imaginação. O poético entra justamente para sublinhar decisões que talvez não passem pelo racional, que são de outra ordem de sentido. Gaston Bachelard, filósofo francês nascido na segunda metade do século XIX, investigava o devaneio como aquilo capaz de nos libertar de uma "função do real" e, mais: é "o testemunho de uma função do irreal".14 Assim como Warburg e Benjamin, Bachelard não olhava para a imagem como mero documento histórico. Para o filósofo, a imagem exercia uma função no presente. Ela seapresentava como um fenômeno capaz de suscitar devaneios, de suspender brevemente o curso normal do tempo, inaugurando um novo modelo temporal: o poético.

Uma vez realizado, o painel ilumina as afinidades eletivas estruturais entre a produção cultural indígena e a obra de Celeida Tostes, evidenciando aquilo que parece ter sobrevivido através da história no que diz respeito a uma linguagem própria da terra. No sentido de investigar tais sobrevivências, três eixos temáticos foram identificados e cada um deles dá a ver outras produções em cerâmica - de outros tempos e culturas. São eles:

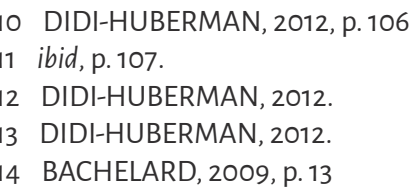




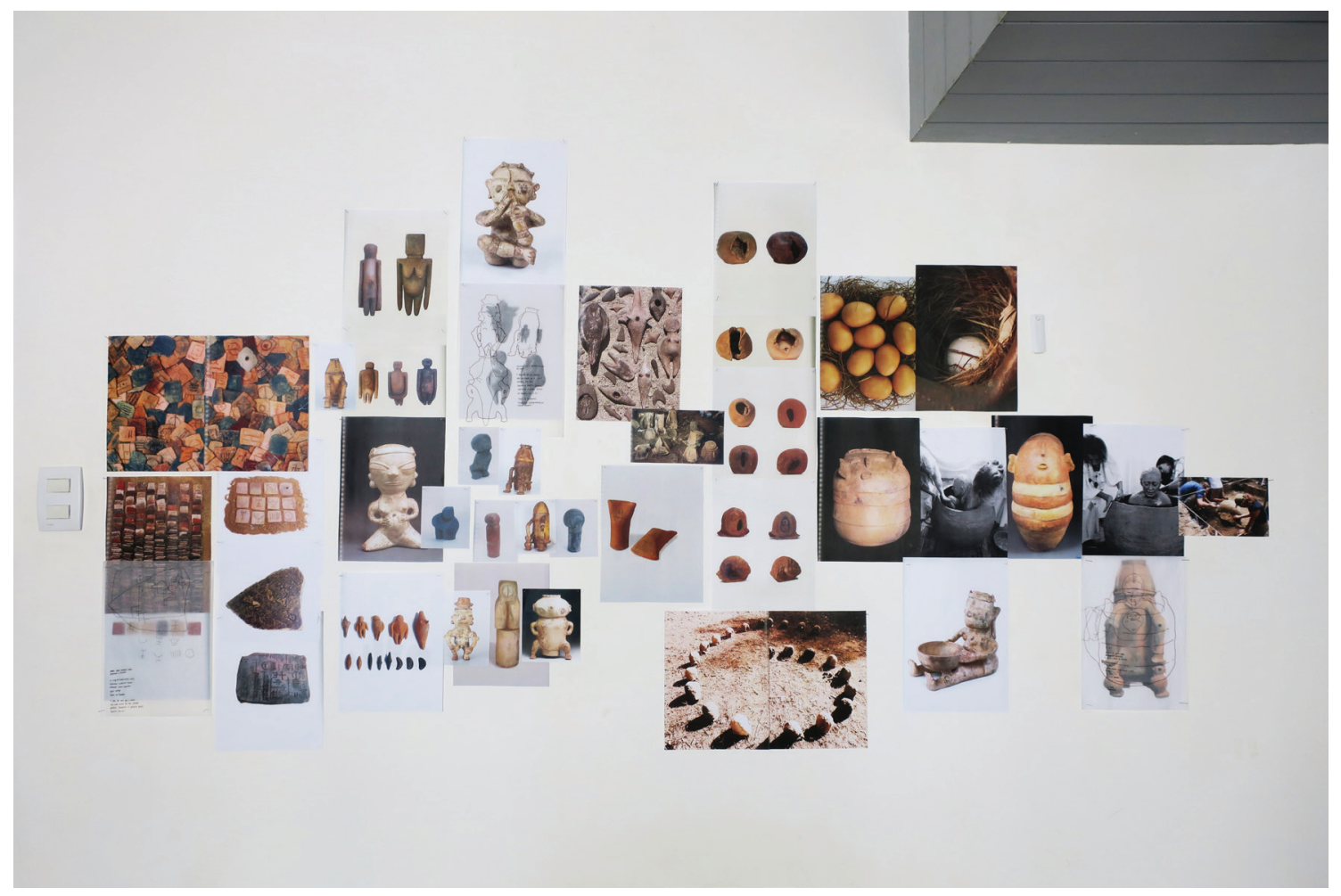

[Figura 1] Painel desenvolvido com imagens dos catálogos da exposição Brèsil Indien e da artista Celeida Tostes.

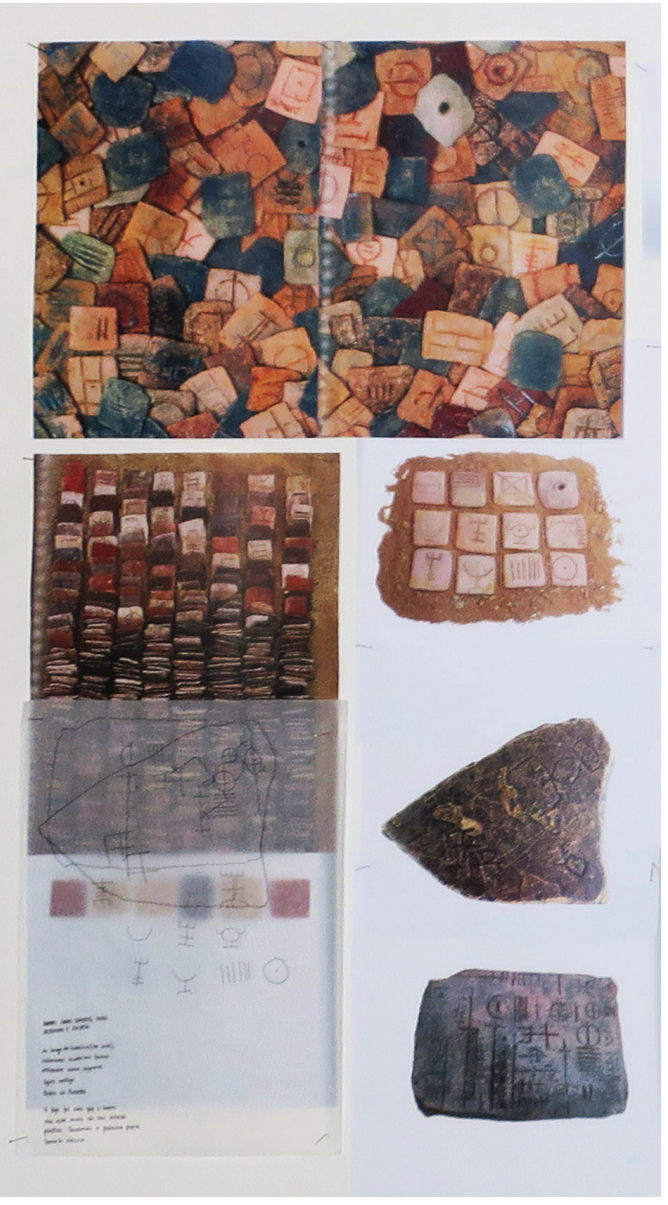

[Figura 2] Detalhe do painel.

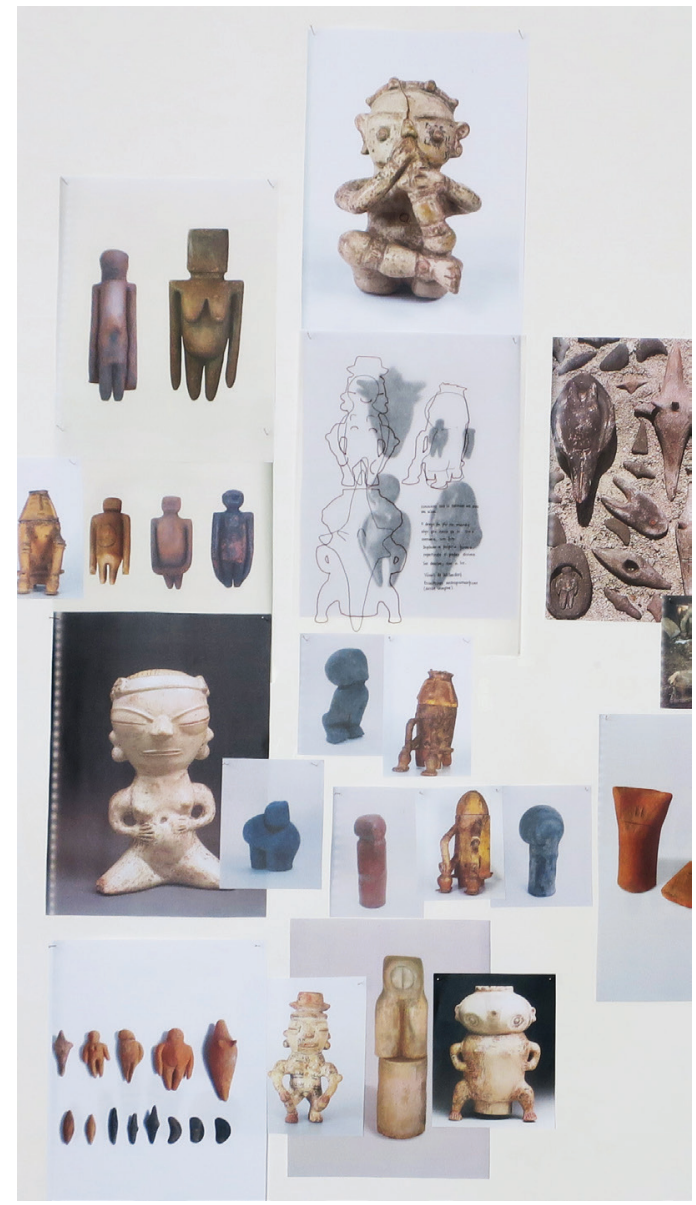

[Figura 3] Detalhe do painel. 


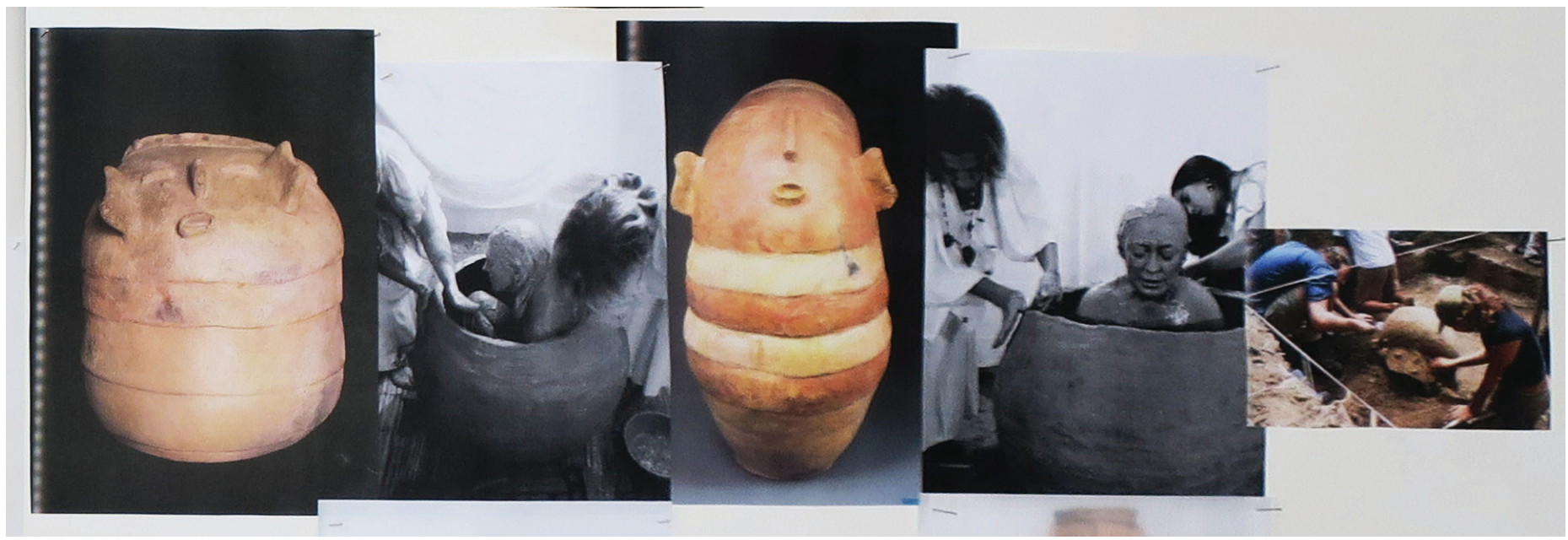

[Figura 4] Detalhe do painel.
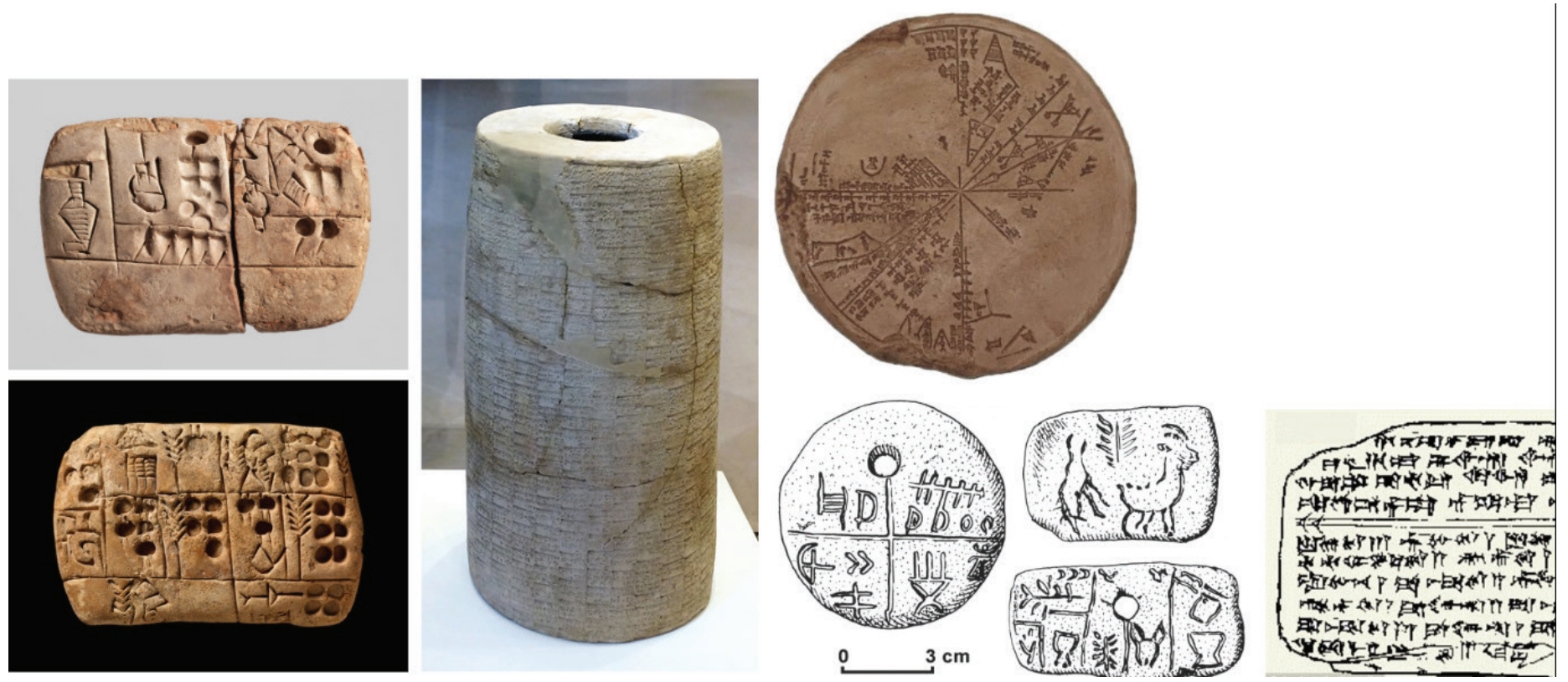

[Figura 5] Diversos exemplos de escrita cuneiforme. 


\section{Selos e Escrituras}

O primeiro eixo temático diz respeitos às inscrições na argila. No painel, um bloco de pedra com gravura, encontrado na Bacia do Rio Amazonas, e imagens da série "Selos" (1982) de Celeida Tostes são colocados lado a lado. Por um instante, as imagens se confundem e torna-se difícil distinguir o que é antigo e o que é contemporâneo. As inscrições, mais ou menos compreensíveis, onde se pode, por vezes, enxergar figuras humanas, ferramentas e elementos da natureza, remetem o espectador a mais ancestral forma de escrita, a escrita cuneiforme. Inscrever no barro é gesto potente, pois a massa, depois de queimada, transforma-se em algo duradouro que responde a um tempo-mineral, que se conta em milênios.

O cozimento das massas vai complicar ainda mais o estudo dos valores imaginários. Não só um novo elemento, o fogo, vem cooperar para a constituição de uma matéria que já reuniu os sonhos elementares da terra e da água, mas também, com o fogo, é o tempo que vem individualizar fortemente a matéria. ${ }^{15}$

As escrituras em cerâmica parecem revelar um desejo muito humano pela transmissão de conhecimento através da linguagem. Cria-se, a nível individual e coletivo, uma memória que sobrevive a quem escreve. Quando Celeida retorna a esta escrita ancestral, inventando todo um vocabulário para si, dá a ver que esse desejo de permanência também sobrevive. (Figura 5)

\section{Figuras antropomórficas}

Este é, talvez, o eixo temático mais rico. Todas as civilizações desenvolveram algum tipo de estatueta antropomórfica em barro ou em outros materiais. A ideia de um criador que modela no barro a forma humana, soprando-Ihe, em seguida, vida, também está presente em diversas culturas, como nos mitos de origem dos maias, chineses e gregos. ${ }^{16} \mathrm{~A}$ Bíblia cristã assim descreve a criação da humanidade. Na cosmologia judaica, há um personagem folclórico chamado Golem que é muitas vezes feito de barro e está associado a sabedoria e ao divino.

No painel, as figuras antropomórficas produzidas pelas populações originárias misturam-se às "Vênus" criadas por Celeida Tostes (série de 1979). As Vênus, as que deram origem à série de Celeida, são um conjunto de estatuetas encontradas em diversos lugares do mundo e que constituem as 
primeiras figuras antropomórficas produzidas pela humanidade. Não se sabe ao certo porque eram produzidas, mas o desejo de reproduzir a forma humana em outra escala e animá-la no quente sopro do interior do forno está presente em todas as culturas. (Figura 6)

Oco

O terceiro eixo temático diz respeito às urnas funerárias indígenas e à performance de Celeida Tostes, "Passagem" (1979). Ao se colocar dentro de um ovo de cerâmica, Celeida evoca a imagem do útero e propõe para si um renascimento. Renasce como um ser feito de terra, coberto de barro molhado. Se aproxima dos mitos de origem, mas não os reencena; os vive. No entanto, a imagem produzida - a de uma mulher sendo aos poucos encerrada em um oco de terra, em um enorme pote de barro feito sob medida para seu corpo adulto - também permite que se veja a morte.

Ao longo do tempo, diversas culturas produziram urnas funerárias em cerâmica para abrigar os seus mortos. As urnas indígenas são decoradas com olhos, narizes e bocas - figuras antropomórficas, completamente ocas, recipientes eternos de seres humanos. Aproximar as imagens de produção cultural ancestral com os registros fotográficos da performance de Celeida Tostes parece agregar - a ambas - camadas de complexidade imprevistas. Enquanto a obra da artista torna-se fúnebre, as urnas parecem prometer uma "sobre vida" / sobrevivência para aquele que foi ali enterrado. Essa abordagem ganha força quando essas imagens se aproximam de uma outra: no Egito, algumas crianças eram enterradas em grandes "ovos" de cerâmica, potes que se assemelhavam a úteros, para que seus renascimentos fossem assim garantidos. ${ }^{17}$ (Figura 7)

A partir dos eixos temáticos, é possível pensar no deslocamento de artefatos etnográficos e arqueológicos para o âmbito da arte. Alfred Cell, antropólogo norte-americano, propôs uma forma de se compreender objetos etnográficos dentro de contextos artísticos e de circuitos de arte, a partir de um estudo de caso, onde examina uma rede de pesca africana exposta como objeto de arte dentro de uma galeria de arte africana. O antropólogo defende que a teoria institucional da arte - para qual é a instituição que legitima um objeto como sendo "de arte" - não é suficiente para dar conta da questão, uma vez que, se assim fosse, qualquer objeto colocado dentro de um museu seria compreendido como obra de arte. O autor coloca que um objeto de arte carrega em si uma 

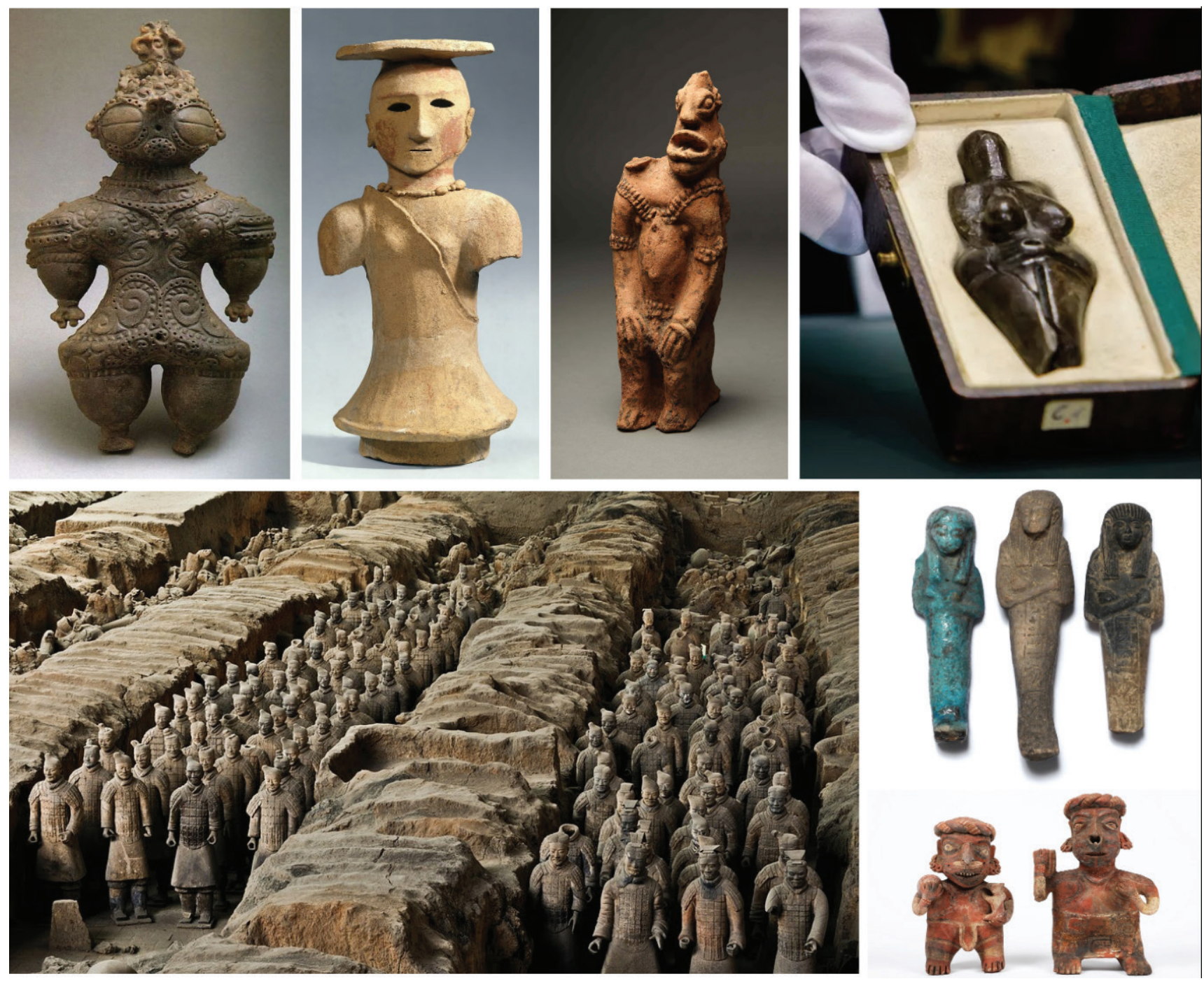

[Figura 6] Figuras antropomórficas de diversos países. Dogu (Japão, 1000 - 400 a.C.) / Haniwa (Japão, século V - VI) / Figura (Gana, - 1400 a.C.) / Vênus Dolni Vestonice (Rep. Tcheca, 27.000 a.C.) / Guerreiros de Terracota (China, 200 a.C.) / Figuras egípcias (1500 - 1000 a.C.) / Figuras pré-colombianas (México, 250 a.C. - 250 d.C.)
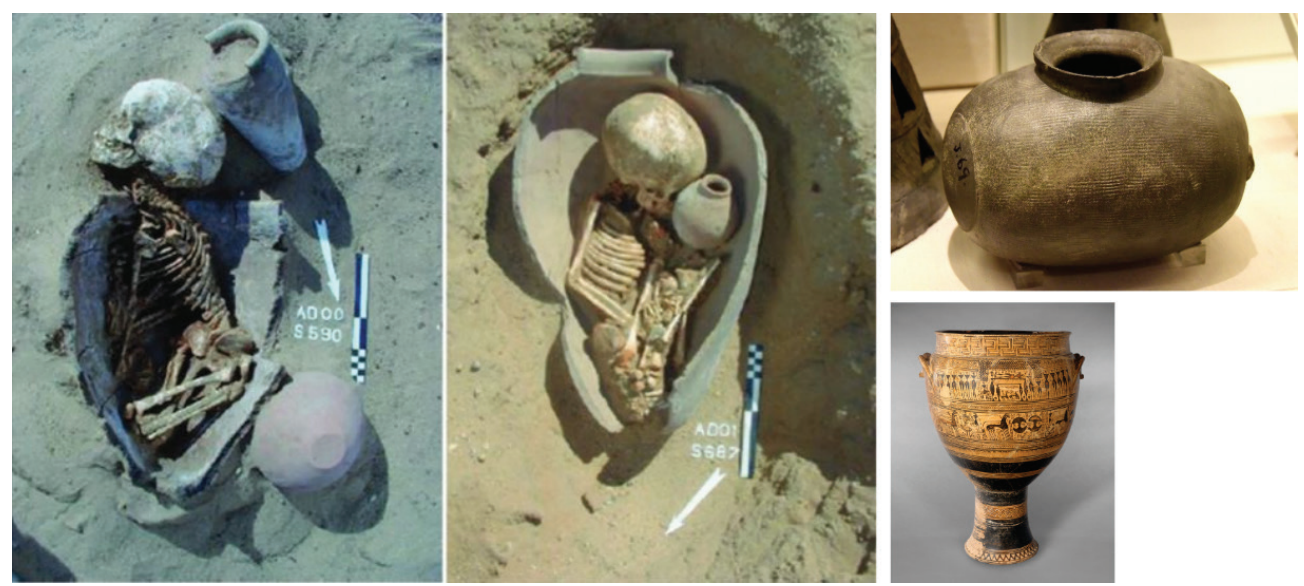

[Figura 7] Urnas e monumentos funerários de diversos países. Urnas funerárias de crianças (Egito, 5500 - 2700 a.C.) / Objeto funerário (Japão, 500 d.C.) / Monumento funerário (Grécia, 750 - 735 a.C.) 
bagagem conceitual mais complexa, que extrapola a instituição onde está inserida. A partir dessa constatação, Gell defende que a antropologia da arte "deveria tratar de fornecer um contexto crítico que liberasse os 'artefatos' e permitisse sua circulação como obras de arte, exibindo-os como encarnações ou resíduos de intencionalidades complexas". ${ }^{8}$

Pode-se dizer que não é possível fazer qualquer tipo de aproximação entre produção cultural indígena e a obra de uma artista contemporânea, porque são coisas completamente disparatadas no tempo. Pode-se também supor que Celeida Tostes tinha conhecimento da produção cultural indígena e que se inspirava ou se apropriava desse vocabulário ancestral para a produção de suas peças, inseridas em circuitos de arte contemporânea. Por outro lado, é possível pensar a partir da materialidade (ou seja, da terra, do barro e da cerâmica), para além dos relativismos culturais que se fariam necessários nessa situação, e observar que os procedimentos técnicos e os resultados formais se assemelham por causa da matéria. E mais, que ao se aproximarem, tanto a produção cultural indígena quando a obra de Celeida Tostes, ganham novas possibilidades de abordagem, pois podem ser compreendidas a partir de um vasto repertório conceitual e cultural, dando a ver, desses encontros, as intencionalidades complexas defendidas por Gell.

Essa pluralidade de saberes que se revela nas intencionalidades complexas, em conjunto com os saberes próprios da cerâmica - os que se aprende com a ponta dos dedos -, amplia o leque antropológico da terra. Dessa forma, é possível construir uma narrativa anacrônica da história da arte, que passa ao largo da ideia de "evolução" técnica. Narrativa de sobrevivências, fissuras, encontros, latências, sintomas, montagens, onde o material-duração conserva, dentro de seus minúsculos grãos, o suave calor das mãos que lhe deram forma.

18 GELL, 2001, p. 190 


\section{Referências Bibliográficas}

BACHELARD, G. A poética do devaneio. São Paulo: Editora WMF Martins Fontes, 2009.

BACHELARD, G. A terra e os devaneios da vontade: ensaio sobre a imaginação das forças. São Paulo: WMF Martins Fontes, 2013.

COSTA, M. L.; SILVA, R. Celeida Tostes. Rio de Janeiro: Memória Visual, 2014.

DIDI-HUBERMAN, G. Diante do tempo: história da arte e anacronismo das imagens. Belo Horizonte: Editora UFMG, 2012.

GELL, Alfred. A rede de Vogel: armadilhas como obras de arte e obras de arte como armadilhas. In: Arte \& Ensaios, Revista do Programa de Pós-graduação em Artes Visuais da EBA/UFRJ, Rio de Janeiro, ano VIII, n. 8, pp. 174-191, 2001.

HENNIG, I. Celeida Tostes e a narrativa do feminino. In: Arte \& Ensaios, Revista do Programa de Pós-Craduação em Artes Visuais da EBA/UFR], Rio de Janeiro, ano XV, n. 17, p. 17-23, 2008.

LACROU, E. Arte indígena no Brasil: agência, alteridade e relação. Belo Horizonte: C/Arte, 2009.

PRADO, J. A arte cerâmica de Minas Gerais. Belo Horizonte: C/Arte, 2018.

SANTOS, E. R. Celeida Tostes: o barro como elemento integrativo na Arte Contemporânea. São Paulo: [s.n.], 2011.

SHAPIRO, R.; HEINICH, N. When is artification? Contemporary Aesthetics, Special Volume 4, 2012. Disponível em: http://www.contempaesthetics.org/newvolume/pages/article.php?articleID=639

SKOLIMOSKI, K. Cosmologia da teoria e na prática: possibilidades e limitações no ensino. 2014. 251 f. Dissertação (Mestrado em Ensino de Ciências) - Interunidades em Ensino de Ciências, Universidade de São Paulo, São Paulo, 2014. 